\title{
Porque Pirilampiscam os Pirilampos - E muitas outras perguntas LUMINOSAS SOBRE QUÍMICA
}

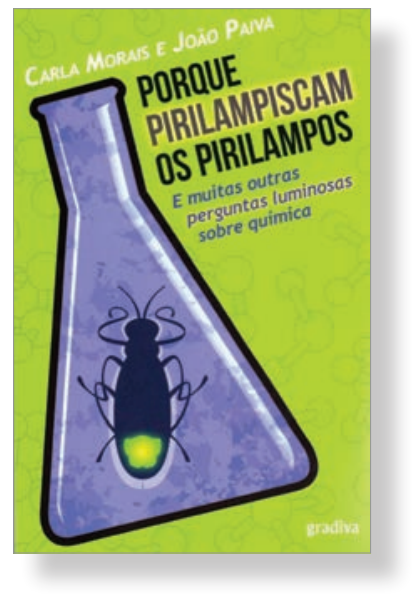

Sérgio P. J. Rodrigues*
A Química é uma das ciências que mais impacto tem nas nossas vidas. É por isso paradoxal o pequeno número de divulgadores desta ciência em relação aos provenientes de outras áreas.

Em "Porque Pirilampiscam os Pirilampos - E muitas outras perguntas luminosas sobre química”, Carla Morais e João Paiva divulgam a Química de forma clara e rigorosa sem simplificações nem excessos didácticos. Numa prosa agradável, através de perguntas, curiosidades e vinhetas informativas, os autores apresentam várias facetas da Química, realçando o seu papel central tanto no dia-a-dia como na identificação e procura de soluções para os problemas do mundo actual.

Numa altura em que jovens e adultos passam tanto tempo ligados a redes sociais, Internet e televisão que lhes trazem constantemente novos estímulos e conteúdos, quase não há tempo para colocar questões e pensar de forma crítica nas respostas. Este livro propõe outro ritmo e pode ser lido, folheado ou consultado por alunos dos últimos anos do ensino básico, alunos do ensino secundário, adultos curiosos e professores (que podem encontrar neste livro novos temas e abordagens para ensinar Química). Realço em particular as questões relativas à química verde, novos materiais e aplicações médicas.

As 37 perguntas e respostas, assim como as 63 curiosidades e 111 vinhetas informativas, podem funcionar como catalisadores de novas questões e estimular milhares de interrogações, que serão ainda poucas comparadas com todas as perguntas que se poderiam fazer com base nos oitenta milhões de substâncias que são conhecidas da Química (mais de três mil descobertas todos os dias), assim como todos os processos em que estas substâncias estão envolvidas.

A pergunta que tão gostosamente dá título ao livro conduz-nos a uma imagem luminosa do papel da Química em tudo

* spjrodrigues@ci.uc.pt

1 Na ausência de perturbações como a convecção e as correntes de ar, as quais aceleram a velocidade de mistura dos gases, a difusão das moléculas é muito lenta devido aos choques entre estas. o que nos rodeia. O químico pergunta como é produzida a luz que emitem os pirilampos; questiona se pode produzir essa luz no laboratório e usar as moléculas que a emitem para alguma coisa. O biólogo procura saber porque é que os pirilampos emitem luz em vez de produzirem sons ou fazerem danças especiais. Sem a Química, o biólogo veria e contaria as luzinhas que acendem e apagam, mas não saberia que estas eram devidas à luciferina. Com a ajuda da Química o bioquímico pode entender o mecanismo e o biólogo molecular pode induzir alterações genéticas para manipular a bioluminescência.

As novas interrogações que as perguntas podem suscitar nem sempre têm resposta fácil. É por isso que precisamos de investigar e estudar, para responder a perguntas e encontrar respostas. A pergunta "Porque sentimos o cheiro de um perfume logo que abrimos o frasco?” leva-nos, como muito bem referem os autores, à existência de moléculas, neste caso voláteis, que estão constantemente em agitação e que se movimentam de forma muito rápida. Mas podemos continuar a fazer perguntas mais ou menos relacionadas: porque é que essas substâncias se deslocam tão rapidamente ou como é que o nosso nariz as detecta? E podemos começar a fazer perguntas que não nos tinham ocorrido inicialmente ou que resultam de observarmos melhor o fenómeno. Afinal, se abrirmos o frasco muito devagar num local sem correntes de ar, o odor ainda demora um pouco a chegar ao nariz, não é?

A difusão é um processo relativamente lento: uma molécula cheirosa de uma peúga demoraria dias ou semanas a chegar do pé ao nariz, na ausência de perturbações no ar! No entanto, de acordo com a teoria cinética dos gases, essa mesma molécula pode mover-se a mais de cem metros por segundo! E agora, parafraseando Rómulo de Carvalho, diga-me o meu amigo porque põe perfume nos pulsos? ${ }^{1}$

A clareza e entusiasmo dos autores podem ser apreciados tanto neste livro como nas acções de divulgação que dele têm feito. A Química precisa que haja cada vez mais químicos que aceitem o desafio de divulgar a importância desta Ciência. 